\title{
Illustrative Material
}

\section{Figures}

2.1 Framework for assessing the relationship between tourism and climate change. . . . . . . . . . . . . . . . . 8

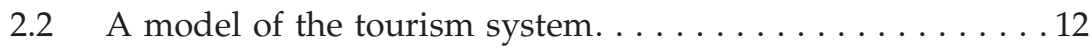

2.3 Contributions of tourism to global climate change . . . . . 17

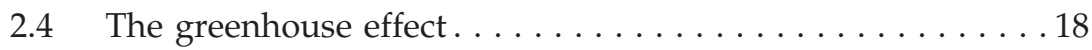

2.5 The Earth system: switch and choke elements . . . . . . . . 19

2.6 Climate-tourism hotspots $\ldots \ldots \ldots \ldots \ldots \ldots \ldots \ldots$

2.7 Chaos model of tourism . . . . . . . . . . . . . 33

3.1 The tourism-climate system: Alpine Europe . . . . . . . 37

3.2 Adaptation strategies for ski resorts . . . . . . . . . 40

3.3 Artificial snow making using snow guns . . . . . . . . 41

3.4 The tourism - climate system: small island destinations . . . . .46

3.5 Direct and indirect consequences of climate change for tourism and adaptation measures. . . . . . . . . . 48

3.6 Backpacker accommodation with a solar hot water system

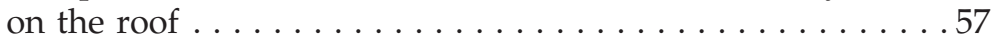

3.7 Climate change impact on the insurance industry and

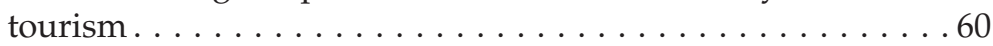

3.8 Number of great natural catastrophes per year. . . . . . . . 61

3.9 Economic losses and insured losses . . . . . . . . . 63

3.10 Costs of damage-causing weather events . . . . . . . 66

3.11 Complete devastation of Niue after cyclone Heta . . . . . . 68

3.12 GHG emissions from aviation. . . . . . . . . . 72

3.13 International tourist arrivals worldwide: Long-haul versus intra-regional trips $1995-2020 \ldots \ldots \ldots \ldots \ldots \ldots 73$

3.14 Impacts of aviation on the atmosphere . . . . . . . . 74

3.15 Estimates of the globally and annually averaged radiative forcing $\left(\mathrm{W}_{\mathrm{m}}^{-2}\right)$ from subsonic aircraft emissions in 1992 .....75

3.16 Example of an emission charge. . . . . . . . . . 81 
4.1 Domestic departures by country of origin. . . . . . . . .93

4.2 International departures by country of origin . . . . . . 994

4.3 Aiding planning of tourism operations by providing information on the weather/climate . . . . . . . . . . 106

4.4 A definition of sustainable tourism provided by the UNWTO . . . . . . . . . . . . . . . . . . . 110

4.5 Keep winter cool campaign . . . . . . . . . . . . . 113

5.1 Atmospheric concentrations for three GHGs, $\mathrm{CO}_{2}$, $\mathrm{CH}_{4}$ and $\mathrm{NO}_{x} \ldots \ldots \ldots \ldots \ldots \ldots \ldots \ldots \ldots \ldots \ldots$

5.2 Storylines for the four IPCC GHG Emissions Scenarios . . 128

5.3 Scenarios of $\mathrm{CO}_{2}$ gas emissions and consequential atmospheric concentrations of $\mathrm{CO}_{2} \ldots \ldots \ldots \ldots \ldots 128$

5.4 Multi-model ensemble annual mean change of temperature for the period 2071-2100, relative to the period 1961-1990, for the B2 emissions scenario . . . . 135

5.5 Multi-model ensemble annual mean change of precipitation for the period 2071-2100, relative to the period 1961-1990, for the B2 emissions scenario . . . . 136

5.6 Relative risks of hospital admissions on consecutive days with high daily maximum Physiological Equivalent Temperature assessed during summer 2003 . . . . . . . . . . 139

5.7 Estimates of changes in temperature and precipitation . . . 141

6.1 Example of energy-related questions for accommodation businesses. . . . . . . . . . . . . . . . . . . . . . . . . . . . . 159

6.2 Deriving energy use and $\mathrm{CO}_{2}$ emissions for a tourist attraction . . . . . . . . . . . . . . . . . . . . . . 160

6.3 Comparison of travel distances for different transport options . . . . . . . . . . . . . . . . . . . . . . . . . . . . . 164

7.1 Global $\mathrm{CO}_{2}$-equivalent emissions from tourism . . . . . . 175

7.2 Passengers at major airports in Great Britain . . . . . . . . . 179

7.3 Airbus $380 \ldots \ldots \ldots \ldots \ldots \ldots$. . . . . . . . . . . . 182

7.4 Comparison of the energy use and $\mathrm{CO}_{2}$ emissions for a journey from Frankfurt to Munich by rail and car . . . . . . 194

7.5 Sightseeing of Angkor Watt (Cambodia) by bike. . . . . . . 202

7.6 Annual energy demand and capacity for different accommodation categories in New Zealand; and $\mathrm{CO}_{2}$ emissions per visitor night . . . . . . . . . . . . . . . . 204 
7.7 Breakdown of energy use into fuel sources for accommodation businesses in Viti Levu, Fiji. . . . . . . . . 207

7.8 Example of a solar water system . . . . . . . . . . . . 214

7.9 Solar panels at the Mauna Lani Bay Resort, Hawaii . . . . . . 215

7.10 Expanded scheme for an autarkic $\mathrm{CO}_{2}$-emission free energy supply for holiday facilities. . . . . . . . . . . . . 217

7.11 Carbon cycle and sequestration of $\mathrm{CO}_{2}$ through forest sinks . . . . . . . . . . . . . . . . . . . 220

8.1 The likelihood of a given extreme event occurring in Maldives. . . . . . . . . . . . . . . . . . . . . . . . . . 225

8.2 Risk-based approaches to identifying and assessing options for managing the adverse consequences of climate change. . .228

8.3 The principal components of tourism-climate futures . . . 231

8.4 Change in international arrivals and departures due to a global mean temperature increase of $1.03{ }^{\circ} \mathrm{C}$ by $2050 \ldots 232$

8.5 Components of the tourism transportation system sensitive to changes in climate . . . . . . . . . . . . . 234

8.6 Tourism dependencies on coral reefs . . . . . . . . . . 239

8.7 Reforestation of mangrove forest at a tourist resort in Fiji. . . 243

8.8 The resort development path . . . . . . . . . . . . . 256

9.1 Timeline of major events relating to climate change and tourism . . . . . . . . . . . . . . . . 264

9.2 Steps of the Adaptation Policy Framework. . . . . . . . . . 270

9.3 Guidelines for adaptation mainstreaming . . . . . . . . 272

9.4 Framework for assessing company climate change exposure........................ 278

9.5 Decisions made during the construction process and climate change-related factors that need to be considered . . .281

9.6 National policies that have an impact on climate-change risks . . . . . . . . . . . . . . . . . . . . 285

9.7 Policy framework for climate change mitigation

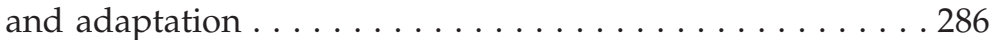

9.8 Seawall to protect beach and tourist accommodation ...... 290

9.9 A normative model of participatory tourism planning . . . . 292

9.10 The roles of knowledge, skills and motivation in responding to climate change . . . . . . . . . . . . . . . 294

9.11 The technology transfer process . . . . . . . . . . . . 296 


\section{Tables}

2.1 Facets of climate and impact on tourists.......... 21

2.2 Importance of destination and climate attributes $\ldots \ldots \ldots 23$

2.3 Climatic information on the three climate-tourism hot spot regions . . . . . . . . . . . . . . 24

3.1 Projected increases in (a) air temperature and (b) changes in precipitation (\%) for small island regions . . . . . . . . 47

3.2 Possible adaptation measures for tourism in small island countries and barriers to implementation.........51

3.3 Adaptation measures taken by accommodation providers in Fiji ........................... 54

3.4 Adaptation measures for tourism and their positive

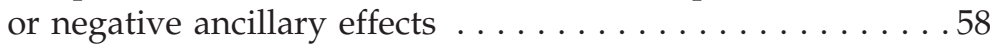

3.5 Damage to livelihoods by hurricane Ivan . . . . . . . . . 62

3.6 Actions to reduce climate change-related loss to the insurance industry . . . . . . . . . . . . . . . . .69

3.7 Potential climate change challenges and opportunities . . . . 70

3.8 Possible schemes for a levy on air travel emissions

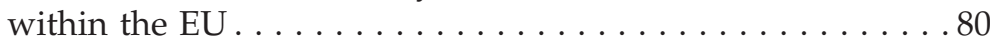

4.1 Top destinations for international tourism $\ldots \ldots \ldots \ldots . . .89$

4.2 Total tourist activity: top 10 countries in the world. . . . . . 90

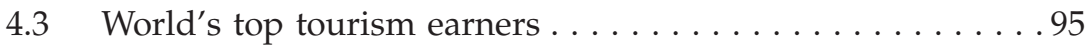

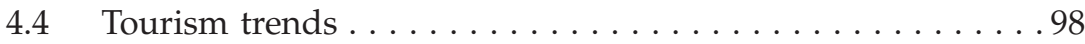

4.5 Examples of tourism niche markets . . . . . . . . . 100

4.6 World arrivals by mode of transport. . . . . . . . . . . 102

4.7 Exemplified positions for light and dark green variants of sustainable tourism. . . . . . . . . . . . . . . . . . 110

5.1 Historical and present concentrations of the main GHGs, their atmospheric lifetimes and their GWPs . . . . . . . . 120

5.2 Forecast international tourist arrivals for 2010 and $2020 \ldots 132$

6.1 Conversion from one form of energy into another and typical efficiencies . . . . . . . . . . . . 146

6.2 Estimated GHG emission factors for European cars . . . . . 149

6.3 Fuel use and average sector distance for representative types of aircraft. . . . . . . . . . . . . . . . . . 154 
6.4 Fleet and fuel consumption data for New Zealand campervan companies . . . . . . . . . . . . . . . . 156

6.5 Emission factors for different transport modes . . . . . . . . 157

6.6 A simplified environmental accounting matrix . . . . . . . 167

6.7 A tourism sector distinguished in an input-output model. . . 170

7.1 Framework for considering transport GHG reductions . . . 177

7.2 Tourist arrivals for main countries of origin, average flying distance, energy use and $\mathrm{CO}_{2}$ emissions. . . . . . . 180

7.3 Energy intensities for various airlines. . . . . . . . . 182

7.4 Breakdown of transport modes for tourism travel in different countries. . . . . . . . . . . . . . . . . 187

7.5 Transport energy efficiencies of transport modes used by tourists . . . . . . . . . . . . . . . . . . . 191

7.6 Energy consumption and emissions per passengerkilometre $(\mathrm{g} / \mathrm{pkm})$ for passenger trains in Denmark. . . . . 193

7.7 Comparison of alternative fuel and vehicle technologies for vehicles . . . . . . . . . . . . . . . . . . . . . . . . . . 197

7.8 Examples of various transport management initiatives . . . 199

7.9 Examples of energy intensities for different accommodation categories . . . . . . . . . . . . . . 205

7.10 Electricity use in Vietnamese hotels . . . . . . . . . . 206

7.11 Energy intensities for different leisure activities . . . . . . . 208

7.12 Practices for energy saving in accommodation businesses . . 210

8.1 Climate change adaptation portfolio for protected area agencies . . . . . . . . . . . . . . . . . . . . . . . . . . 244

8.2 Ideal climate-related requirements for water- and land-based recreation activities . . . . . . . . . . . . . . . . . 249

9.1 GHG emissions and reduction targets for Annex I Parties . . . .266

9.2 Adaptive responses in the case of tourism . . . . . . . 276

9.3 Including climate change risk into financial models for businesses. . . . . . . . . . . . . . . . . . . . 280

9.4 Policy instruments for environmental improvements . . . . 288

\section{Text Boxes}

1 Aspen Skiing Company. . . . . . . . . . . . . . . . . . 44

2 Hurricane Katrina, 29 August 2005 . . . . . . . . . . . . . 65

3 China - major emerging player in global tourism. . . . . . 991 
4 Hypermobility - high-frequency, long-distance travellers . . 108

5 Are tourists sensitive to GHG emissions? . . . . . . . . . . . 111

6 Recent changes in the observed climate. . . . . . . . . . . 121

7 Extreme climatic events in the European Alps . . . . . . . . 123

8 Storylines for tourism, based on the IPCC Scenarios . . . . . . 129

9 El Niño and tourism . . . . . . . . . . . . . . . . . . 137

10 Basic information needed for energy and GHG accounting. . . . 147

11 Auckland International Airport . . . . . . . . . . . . . . . 186

12 European MUSST Project . . . . . . . . . . . . . . . . . 188

13 East Japan Railway Company . . . . . . . . . . . . . . . . . . 192

14 Bad Hofgastein/Werfenweng, Austria . . . . . . . . . . . . . . 201

15 Hong Kong Disneyland. . . . . . . . . . . . . . . . . . . . . 212

16 Tortoise Head Guest House, Australia. . . . . . . . . . . . . . . . 216

17 Carbon offsets and air travel . . . . . . . . . . . . . . . 219

18 Adaptation for coastal tourism . . . . . . . . . . . . . . . 230

19 Climate change and wine tourism . . . . . . . . . . . . . 240

20 Using climate models to assess tourism destinations' competitiveness . . . . . . . . . . . . . . . . . . . 247

21 Climate change and the ski industry . . . . . . . . . . 258

22 Kyoto mechanisms for mitigation . . . . . . . . . . . . . 269

23 Integrating adaptation and mitigation . . . . . . . . . 284

24 Methods to support participatory planning. . . . . . . . . . . 290 